WSRC-STI-2008-00172

Rev. 0

\title{
CLOSURE OF HLW TANKS - FORMULATION FOR A COOLING COIL GROUT
}

\author{
J. R. Harbour, V. J. Williams, and E. K. Hansen \\ Savannah River National Laboratory \\ and \\ W. L. Mhyre \\ Civil Testing Laboratory
}

April 2008

Process Science and Engineering

Savannah River National Laboratory

Aiken, SC 29808

Prepared for the U.S. Department of Energy Under Contract Number DEAC09-96SR18500

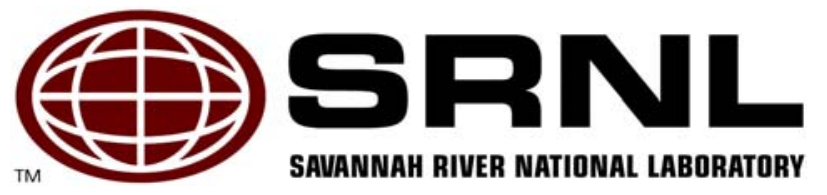




\section{DISCLAIMER}

This report was prepared by Washington Savannah River Company (WSRC) for the United States Department of Energy under Contract No. DE-AC09-96SR18500 and is an account of work performed under that contract. Neither the United States Department of Energy, nor WSRC, nor any of their employees makes any warranty, expressed or implied, or assumes any legal liability or responsibility for the accuracy, completeness, or usefulness, of any information, apparatus, or product or process disclosed herein or represents that its use will not infringe privately owned rights. Reference herein to any specific commercial product, process, or service by trademark, name, manufacturer or otherwise does not necessarily constitute or imply endorsement, recommendation, or favoring of same by WSRC or by the United States Government or any agency thereof. The views and opinions of the authors expressed herein do not necessarily state or reflect those of the United States Government or any agency thereof.

\section{Printed in the United States of America \\ Prepared For U.S. Department of Energy}


Key Words: Tank Closure Chromium Cable Grouts

Retention: Permanent

\title{
CLOSURE OF HLW TANKS - FORMULATION FOR A COOLING COIL GROUT
}

\author{
J. R. Harbour, V. J. Williams, and E. K. Hansen \\ Savannah River National Laboratory \\ and \\ W. L. Mhyre \\ Civil Testing Laboratory
}

April 2008

Process Science and Engineering Savannah River National Laboratory Aiken, SC 29808

Prepared for the U.S. Department of Energy Under Contract Number DEAC09-96SR18500 


\section{REVIEWS AND APPROVALS}

\section{AUTHORS:}

J. R. Harbour, SRNL, Stabilization Science Research

Date

V. J. Williams, SRNL, Stabilization Science Research

Date

E. K. Hansen, SRNL, Engineering Process Development

Date

W. L. Mhyre, WGI, Civil Test Laboratory

Date

\section{TECHNICAL REVIEWERS:}

A. D. Cozzi, SRNL, Stabilization Science Research

Date

\section{APPROVERS}

D. A. Crowley, SRNL, Manager, Stabilization Science Research

Date

J. C. Griffin SRNL, Manager, E\&CPT Research Programs

Date

B. J. Adkins, Liquid Waste Technology Development Engineering

Date

M. J. Mahoney, Manager, Liquid Waste Technology Development Engineering

Date 


\section{EXECUTIVE SUMMARY}

The Tank Closure and Technology Development Groups are developing a strategy for closing the High Level Waste (HLW) tanks at the Savannah River Site (SRS). Two Type IV tanks, 17 and 20 in the F-Area Tank Farm, have been successfully filled with grout. Type IV tanks at SRS do not contain cooling coils; on the other hand, the majority of the tanks (Type I, II, III and IIIA) do contain cooling coils. The current concept for closing tanks equipped with cooling coils is to pump grout into the cooling coils to prevent pathways for infiltrating water after tank closure. This task addresses the use of grout to fill intact cooling coils present in most of the remaining HLW tanks on Site.

The overall task was divided into two phases. Phase 1 focused on the development of a grout formulation (mix design) suitable for filling the HLW tank cooling coils. Phase 2 will be a largescale demonstration of the filling of simulated cooling coils under field conditions using the cooling coil grout mix design recommended from Phase 1.

This report summarizes the results of Phase 1, the development of the cooling coil grout formulation. A grout formulation is recommended for the full scale testing at Clemson Environmental Technology Laboratory (CETL) that is composed by mass of $90 \%$ Masterflow (MF) 816 (a commercially available cable grout) and $10 \%$ blast furnace slag, with a water to cementitious material (MF $816+$ slag) ratio of 0.33 . This formulation produces a grout that meets the fresh and cured grout requirements detailed in the Task Technical Plan (2). The grout showed excellent workability under continuous mixing with minimal change in rheology.

An alternative formulation using $90 \%$ MF 1341 and $10 \%$ blast furnace slag with a water to cementitious material ratio of 0.29 is also acceptable and generates less heat per gram than the MF 816 plus slag mix. However this MF 1341 mix has a higher plastic viscosity than the MF 816 mix due to the presence of sand in the MF 1341 cable grout and a lower water to solids ratio. Nevertheless, the higher viscosity grout may still meet the requirements for the cooling coil grout under certain pumping conditions or alternatively, the mix may be made more fluid by a short period of high shear mixing during production.

The mixes have not been optimized for large scale production. It may be possible, for example, to adjust the water to cementitious materials ratio to provide improved performance of these mixes based on the results and conclusions of the large scale testing at CETL.

Recommendations from this task include incorporation of a backup mixing/pumping system that is either integrated into the system or is available for immediate use in case of a pump or mixer failure of the primary system. A second recommendation is to conduct a laboratory scale investigation to determine the impact of operational variation on the properties of the grout. This effort would be initiated after feedback is received from the large scale testing at CETL. The purpose of this proposed variability testing is to better understand the limits of the operational variations (such as temperature and mixing time), and to identify possible approaches for remediation to ensure that the grout produced will flow effectively in the coils while still meeting the performance requirements. 


\section{TABLE OF CONTENTS}

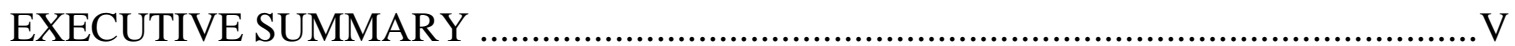

LIST OF FIGURES ..................................................................................... VII

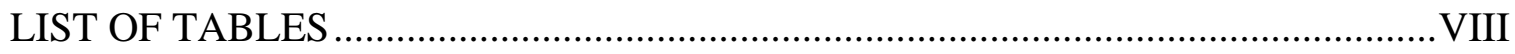

LIST OF ACRONYMS ...................................................................................... IX

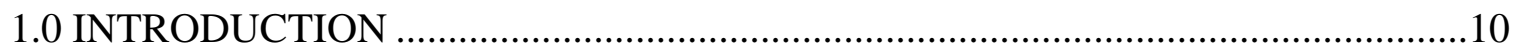

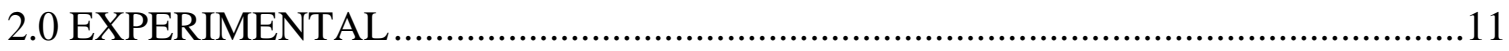

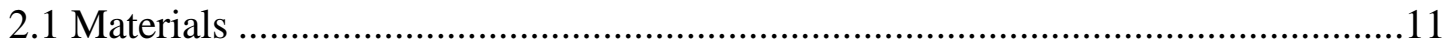

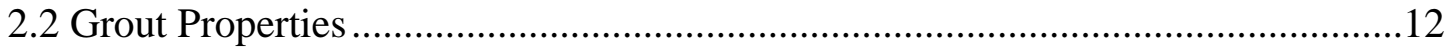

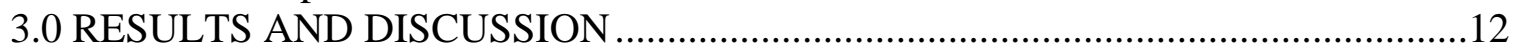

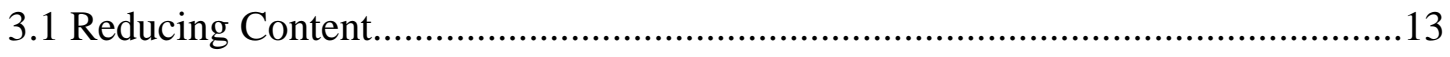

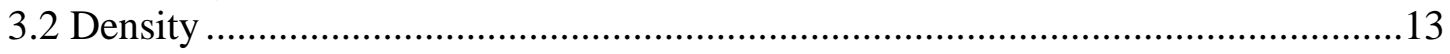

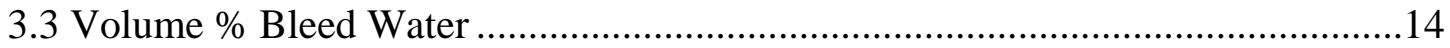

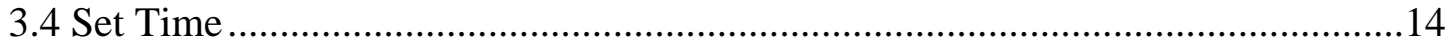

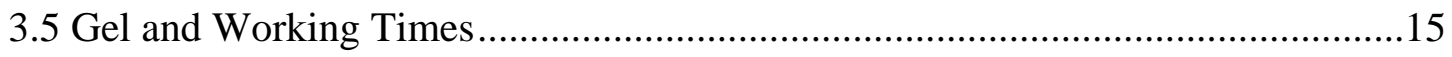

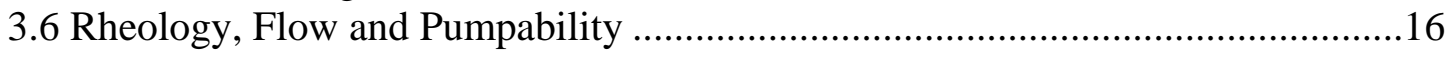

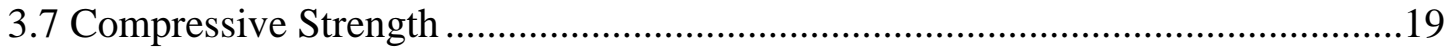

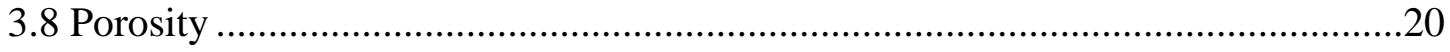

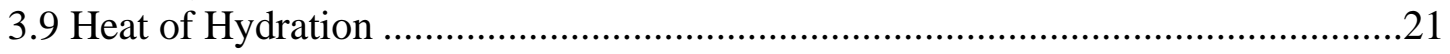

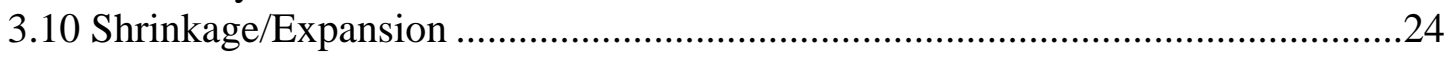

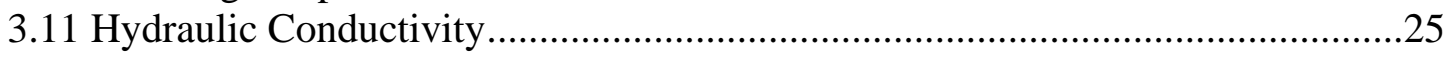

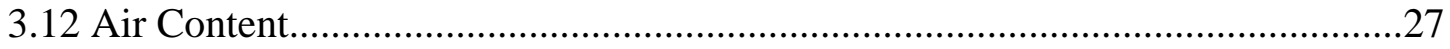

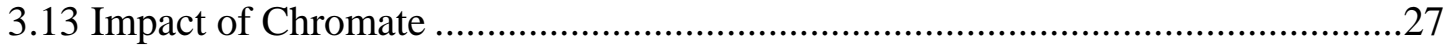

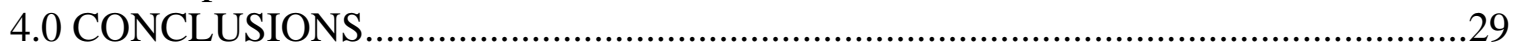

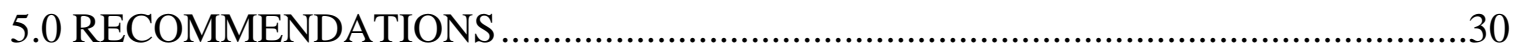

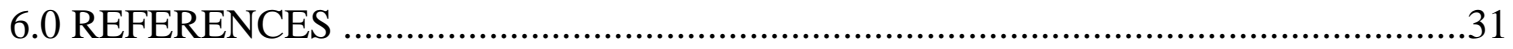




\section{LIST OF FIGURES}

Figure 3-1 ASTM C 939 Flow Cone 18

Figure 3-2 One of the cubes immediately after failure of compressive strength testing 20

Figure 3-3 Normalized heat of hydration for the MF 816 + slag mix 22

Figure 3-4 Normalized heat of hydration for the MF 1341 + slag mix 22

Figure 3-5 Normalized heat of hydration for the OPC + slag mix 23

Figure 3-6 Normalized heat flow for the MF 816 and slag mix 23

Figure 3-7 Cast bar in a micrometer used to measure shrinkage and expansion (N-Area) 25

Figure 3-8 Photograph of the experimental setup at MACTEC for measurement of permeability

Figure 3-9 Photograph of the molds in which the samples were cast and cured for 28 days prior

to removal and measurement at MACTEC (TR 405 is the mix containing MF 816 and slag). 


\section{LIST OF TABLES}

Table 2-1 Saltstone Cementitious Materials ........................................................................ 11

Table 2-2 Cable Grouts Tested in This Task ...................................................................... 11

Table 2-3 Weight Percent Composition of Cable Grouts ..................................................... 11

Table 3-1 Three Mix Design Options for Cooling Coil Grout ............................................... 13

Table 3-2 Reducing Content of the Three Mix Designs for the Cooling Coil Grouts................ 13

Table 3-3 Cured Grout Densities Measured with Pcynometry .................................................. 14

Table 3-4 Volume \% Bleed for the Three Options .................................................................... 14

Table 3-5 Set Time for the Three Mix Design Options ........................................................ 15

Table 3-6 Static Gel Time for the Three Mix Design Options ................................................. 15

Table 3-7 Dynamic Gel Time for the Three Mix Design Options: Rheology as a Function of

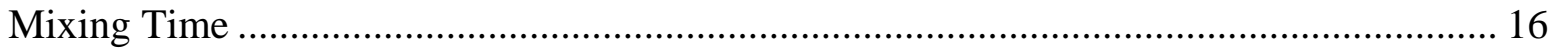

Table 3-8 Pumpability as a Function of Time for the Three Mix Designs ................................ 17

Table 3-9 Flow and Rheological Data for High Shear vs. Low Shear Mixing........................... 17

Table 3-10 Flow values for the Three Mix Designs .............................................................. 18

Table 3-11 Compressive Strengths of the Three Mix Designs for Cooling Coil Grout after 28

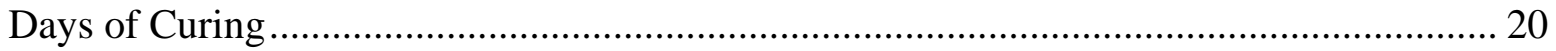

Table 3-12 Porosity Measurements for Samples at Various Curing Times............................... 21

Table 3-13 Normalized Heat of Hydration Data after 20 Days .............................................. 24

Table 3-14 Expansion/Shrinkage Data for the Grouts ......................................................... 24

Table 3-15 Compressive Strength Values for Mixes Made With and Without Chromate .......... 28 


\section{LIST OF ACRONYMS}

\begin{tabular}{|l|l|}
\hline ACTL & Aiken County Technology Laboratory \\
\hline ASTM & American Standard for Testing Materials \\
\hline BFS & Blast Furnace Slag \\
\hline CETL & Clemson Environmental Technology Laboratory \\
\hline cm & Centimeter \\
\hline cP & Centipoise \\
\hline FA & Fly Ash \\
\hline ft $^{3}$ & Cubic feet \\
\hline g & Grams \\
\hline gpm & Gallons per minute \\
\hline HLW & High Level Radioactive Waste \\
\hline J & Joules \\
\hline kg & Kilograms \\
\hline lbm & Pound mass \\
\hline MF & Masterflow \\
\hline mL & Milliliter \\
\hline M & Molar \\
\hline NM & Not Measured \\
\hline OPC & Ordinary Portland Cement \\
\hline Pa & Pascal \\
\hline ppm & Parts per million \\
\hline psi & Pounds per square inch \\
\hline RH & Relative Humidity \\
\hline sec & Seconds \\
\hline SRNL & Savannah River National Laboratory \\
\hline SRS & Savannah River Site \\
\hline TTP & Technical Task Plan \\
\hline TTR & Technical Task Request \\
\hline w/cm & Water to Cementitious Material Mass Ratio \\
\hline WSRC & Washington Savannah River Company \\
\hline Wt \% & Weight Percent \\
\hline & \\
\hline
\end{tabular}




\subsection{INTRODUCTION}

This task supports Tank Closure and Technology Development in closing high level radioactive waste tanks. Specifically, this task addresses the use of grout to fill the intact cooling coils present within the High Level Waste (HLW) tanks. The overall task was divided into two phases. Phase 1 focused on the development of a grout formulation suitable for filling the HLW tank cooling coils. Phase 2 will be a large-scale demonstration of the filling of cooling coils under simulated field conditions using the cooling coil fill grout recommended from Phase 1 of this work. This report presents the results of cooling coil grout development under Phase 1 of the task and provides a recommendation of a mix design (grout formulation) for Phase 2.

The current concept for closing tanks equipped with internal cooling coils is to pump grout into the coils to prevent pathways for infiltrating water. Access to the cooling coils will be through existing headers located on top of the tanks. This work was initiated through a Task Technical Request (TTR) (1).

The required fresh and cured properties of the cooling coil fill grout were identified in meetings with the Tank Closure and Technology Development customer. These properties include physical, chemical, hydraulic properties and pumping requirements. Grout property requirements have been detailed in reports (1-3). The maximum pumping requirements and system limitations were established by B. J. Adkins (4). 


\subsection{EXPERIMENTAL}

\subsection{Materials}

The ordinary portland cement (OPC) and blast furnace slag (BFS) used in this task were obtained from the Saltstone Production Facility in 5 gallon containers and are listed in Table 2-1. These materials were specified in a WSRC contract for Saltstone cementitious materials and arrived with the delivery of the cementitious materials to Saltstone. The materials were transferred to 2 liter plastic bottles at Aiken County Technology Laboratory (ACTL) and tightly sealed. Maintaining these materials in a tightly sealed container limits the exposure of the materials to humid air.

Table 2-1 Saltstone Cementitious Materials

\begin{tabular}{|c|c|c|}
\hline Material & Category & Vendor \\
\hline $\begin{array}{c}\text { Ordinary Portland Cement } \\
\text { (OPC) }\end{array}$ & Type II & Holcim \\
\hline Blast Furnace Slag (BFS) & Grade 100 & Holcim \\
\hline
\end{tabular}

The cable grouts used in this study are commercially available grouts which were received in 50 to 55 pound bags. Table 2-2 lists the cable grouts that were tested as part of this task. The compositions of the two cable grouts selected for additional study are provided in Table 2-3 and are based on the Materials Safety Data Sheets provided by the vendor.

Table 2-2 Cable Grouts Tested in This Task

\begin{tabular}{|c|c|c|}
\hline Cable Grout & Aggregate Present & Vendor \\
\hline Masterflow (MF) 816 & No & BASF \\
\hline MF 1341 & Yes & BASF \\
\hline Crystex & Yes & L \& M Construction Chemicals \\
\hline Duragrout & Yes & L \& M Construction Chemicals \\
\hline SikaGrout 328 & Yes & Sika Corporation \\
\hline Euco PTX & No & Euclid Chemical Company \\
\hline
\end{tabular}

Table 2-3 Weight Percent Composition of Cable Grouts

\begin{tabular}{|c|c|c|c|c|c|c|c|c|}
\hline $\begin{array}{l}\text { Cable } \\
\text { Grout }\end{array}$ & 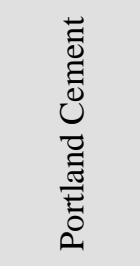 & 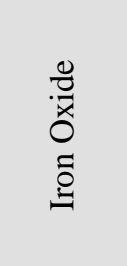 & 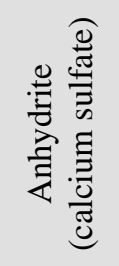 & 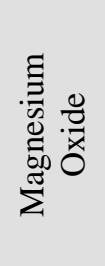 & 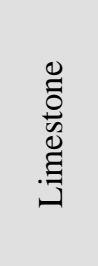 & 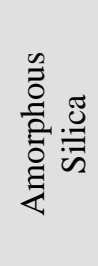 & 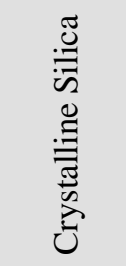 & 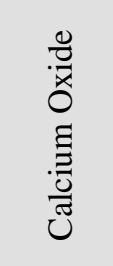 \\
\hline MF 816 & $30-60$ & $10-30$ & $7-13$ & $3-7$ & $3-7$ & $1-5$ & $0.1-1$ & $7-13$ \\
\hline MF 1341 & 30 & - & - & 5 & 5 & 5 & 35 & 5 \\
\hline
\end{tabular}


ADVA 190 is a polycarboxylate based high range water-reducing admixture that was used in the mix designs containing OPC and BFS. This admixture complies with specifications for chemical admixtures for Concrete, ASTM C 494, as type A and F. It is produced by Grace Construction Products.

For those tests which included chromate in the mixing water, a $750 \mathrm{ppm}$ chromate solution was prepared using potassium dichromate that included sodium hydroxide $\left(10^{-3} \mathrm{M}\right)$. This solution was used to simulate the maximum concentration of chromate in the cooling coils.

\subsection{Grout Properties}

The methods used for the measurements of both fresh and cured grout properties have been discussed previously (5-7). Hydraulic conductivity measurements were performed by MACTEC, Atlanta, Georgia following ASTM D 5084, method F. MACTEC performed the measurements using mercury rather than water to provide a larger head with the falling head method.

\subsection{RESULTS AND DISCUSSION}

Two approaches were used to develop a mix design (also referred to as the grout formulation) for the cooling coil grout. The first approach used commercially available cable grouts to which BFS was added to meet the requirement for reducing capacity. Typically, the amount of BFS added was $10 \mathrm{wt}$. \% BFS relative to the amount of dry cable grout and BFS. A list of the cable grouts tested in this study is provided in the Experimental Section, 2.1. The second approach used a combination of OPC and BFS at low water to cementitious materials ratios facilitated through the use of a superplasticizer. As with the cable grouts, BFS was included in the mix design to provide reductive capacity. For the second approach, a superplasticizer admixture, ADVA 190, was introduced to improve mixing and flow.

A down selection was made to three mix designs after testing a variety of cable grout/BFS mixes and a number of OPC/BFS mixes. The three selected mix designs are provided in Table 3-1. The down selection was made to include one mix each of an aggregate free cable grout, an aggregate containing cable grout, and an OPC/slag containing grout. Selection criteria included ease of mixing, flowability, and lack of aggregate separation. The OPC/slag option was selected based on best properties as a function of $\mathrm{w} / \mathrm{cm}$ ratio and admixture dose. This down selection does not necessarily exclude the other cable grouts as viable options.

The fresh and cured properties results of these three grout options are presented in this section of the report. These mixes were tested mainly at $22{ }^{\circ} \mathrm{C}$ using a paddle blade mixer with a $1.6 \mathrm{~kg}$ total batch mass (5). Several mixes were prepared using a high shear mixer for comparison. 
Table 3-1 Three Mix Design Options for Cooling Coil Grout

\begin{tabular}{|c|c|c|c|}
\hline Mix Identifier & $\begin{array}{c}\text { Wt\% slag per unit } \\
\text { mass dry material }\end{array}$ & $\begin{array}{c}\text { Water to cementitious } \\
\text { mass ratio }\end{array}$ & Admixture \\
\hline MF $816+$ slag & 10.0 & 0.33 & None \\
\hline MF $1341+$ slag & 10.0 & 0.29 & None \\
\hline OPC + slag & 10.0 & 0.35 & ADVA 190 @ 3 mL/1600g of mix \\
\hline
\end{tabular}

The study of the impact of operational variation on the properties discussed below was not included in the scope of this task but was identified in the TTP (2) as conditional dependent on funding and the results from the full scale testing. This additional study would provide understanding of the robustness of the design mix to variations in temperature, water to powder ratio, slag to OPC ratio, slag to cable grout ratio, and mixing method. This study would also identify the areas where changes to the mix design or adjustments to the temperature of the mix water may be required to ensure proper placement while still meeting the property specifications.

\subsection{Reducing Content}

A requirement for the mix design developed for the cooling coil grout is a reducing capacity at least as great as the mix design for the reducing tank fill grout - OPDEXE-X-P-0-BS (8). The mix design for the reducing tank fill grout contained $7.1 \mathrm{wt} \%$ of slag (the material which contains the reducing capacity) relative to dry ingredients (OPC, BFS, FA and sand) and $6.1 \mathrm{wt} \%$ slag relative total mass of the mix. Table 3-2 presents the relative amounts of slag present in the final three mix designs investigated in this report. This data shows that the requirement for reducing content for these grouts has been met.

Table 3-2 Reducing Content of the Three Mix Designs for the Cooling Coil Grouts

\begin{tabular}{|c|c|c|}
\hline Mix Identifier & $\begin{array}{c}\text { Wt \% slag per unit } \\
\text { mass dry material }\end{array}$ & $\begin{array}{c}\text { Wt \% slag per } \\
\text { total mass }\end{array}$ \\
\hline MF 816 + slag & 10.0 & 7.5 \\
\hline MF 1341 + slag & 10.0 & 7.8 \\
\hline OPC + slag & 10.0 & 7.4 \\
\hline
\end{tabular}

\subsection{Density}

The density of the cooling coil grouts is required to be in the range of 93.6 to $135 \mathrm{lbm} / \mathrm{ft}^{3}$ (1.50 to $2.16 \mathrm{~g} / \mathrm{mL}$ ). The cured grout densities were measured using a pycnometer (7). The density results of the final three mix designs are provided in Table 3-3. All three options produced cured grouts with densities at the higher end of the acceptable range. Fresh grout densities were also measured and were typically slightly less than the cured grout densities. For example the average of all measurements of fresh grout density for MF 816 grout + slag at a w/cm ratio of 0.33 was $2.00 \mathrm{~g} / \mathrm{mL}$ as compared to $2.07 \mathrm{~g} / \mathrm{mL}$ cured. A reason for the lower fresh grout density could be due to air entrainment in the fresh grout. 
Table 3-3 Cured Grout Densities Measured with Pcynometry

\begin{tabular}{|c|c|}
\hline Mix Identifier & Cured Grout Density $\mathbf{( g / m L )}$ \\
\hline MF 816 + slag & 2.07 \\
\hline MF 1341 + slag & 2.06 \\
\hline OPC + slag & 2.04 \\
\hline
\end{tabular}

\subsection{Volume \% Bleed Water}

The TTR (1) specifies that the grout must exhibit minimal bleed. SRNL typically measures the volume \% bleed water after 1 and 3 days (5). For the three options for the cooling coil grout, no bleed water was evident after 1 (or 3 day) for any of the samples (see Table 3-4). Because the samples are cast and sealed within a vessel, some condensed water was evident on the top inside surface of the cover. This volume of water was small and was a result of the method of testing rather than representative of the environment in the cooling coils. In addition, no bleed water was evident immediately after pouring or at any time on the grout surface for both the MF 816 and MF 1341 mixes. This was not the case for the OPC/slag mix which exhibited a small amount of bleed water for several hours after mixing. The bleed water from this mix was slowly reabsorbed such that no water was observed on the grout surface at the time of the 1 day measurement. This observation of initial bleed water with the OPC + slag option could result in residual water on the top surface of the grout in the cooling coil and reabsorption in that configuration may not occur. The three final grout options readily meet the volume \% bleed requirement after 1 and 3 days.

Table 3-4 Volume \% Bleed for the Three Options

\begin{tabular}{|c|c|c|}
\hline \multirow{2}{*}{ Mix Identifier } & \multicolumn{2}{|c|}{ Volume\% Bleed } \\
\cline { 2 - 3 } & Initial & 1-Day \\
\hline MF 816 + slag & 0.00 & 0.00 \\
\hline MF 1341 + slag & 0.00 & 0.00 \\
\hline OPC + slag & $\sim 0.5$ & 0.00 \\
\hline
\end{tabular}

\subsection{Set Time}

The requirement for set time is 24 hours or less as measured using a Vicat needle. All three mix designs set within 24 hours (Table 3-5), thereby satisfying the set time requirement. The set time with the Vicat needle is measured every 24 hours and consequently, no differentiation of set times less than 24 hours among the three options was made. 
Table 3-5 Set Time for the Three Mix Design Options

\begin{tabular}{|c|c|}
\hline Mix Identifier & Set Time (Hours) \\
\hline MF $816+$ slag & $<24$ \\
\hline MF $1341+$ slag & $<24$ \\
\hline OPC + slag & $<24$ \\
\hline
\end{tabular}

\subsection{Gel and Working Times}

The specifications (2) require a static gel time of 5 minutes or longer and a dynamic gel time (also referred to as working time) of 30 minutes or longer. The results of static gel time are provided in Table 3-6.

Table 3-6 Static Gel Time for the Three Mix Design Options

\begin{tabular}{|c|c|}
\hline Mix Identifier & Static Gel Time (Minutes) \\
\hline MF 816 + slag & 5 to 10 \\
\hline MF $1341+$ slag & 5 to 10 \\
\hline OPC + slag & 60 \\
\hline
\end{tabular}

Cable Grout vendors do not specify static gel times, because it is assumed that the grout will be mixed continuously until placement. The vendors recommend that a backup mixing/pumping system is either integrated or available for immediate use in case of a pump or mixer failure of the primary system. If a backup mixing/pumping system is not available, then a water flush line, with adequate pressure must be readily available to flush out the grout in the lines. These backup systems would be required regardless of any reasonable value of the static gel time in order to avoid set up of the grout within the mixer/pump/process lines.

The dynamic gel time (working time) should be as long as possible to provide the operator sufficient time to pump all of the grout into the cooling lines. To determine this dynamic gel time, the grout was continuously mixed for a period of 90 minutes with samples taken every 30 minutes for rheological characterization. The results are presented in Table 3-7 and demonstrate that the dynamic gel times (working times) are greater than 90 minutes for the MF $816+$ slag and the OPC +slag mix design options and greater than 60 minutes for the MF $1341+$ slag option. A successful working time was defined as filling 1200 feet of linear pipe at a minimum of 5 gpm and within the maximum allowable working pressure of the cooling coils, which is 150 psi. (See Section 3.6 and Table 3-8 for a discussion of acceptable pumping conditions). For reference, the time required to fill 1200 feet of 2 " schedule 40 piping at 5 gallons per minute (gpm) is 41 minutes. 
Table 3-7 Dynamic Gel Time for the Three Mix Design Options: Rheology as a Function of Mixing Time

\begin{tabular}{|c|c|c|c|}
\hline \multirow{2}{*}{ Mix Identifier } & $\begin{array}{c}\text { Time } \\
\text { (minutes) }\end{array}$ & $\begin{array}{c}\text { Yield } \\
\text { Stress(Pa) }\end{array}$ & $\begin{array}{c}\text { Plastic } \\
\text { Viscosity(cP) }\end{array}$ \\
\hline \multirow{3}{*}{ MF 816+ slag } & 0 & 3.0 & 283 \\
\cline { 2 - 4 } & 30 & 3.0 & 243 \\
\cline { 2 - 4 } & 60 & 4.1 & 251 \\
\cline { 2 - 4 } & 90 & 5.6 & 270 \\
\hline \multirow{3}{*}{ MF 1341+ slag } & 0 & 8.1 & 811 \\
\cline { 2 - 4 } & 30 & 15.2 & 567 \\
\cline { 2 - 4 } & 60 & 18.7 & 544 \\
\hline \multirow{3}{*}{ OPC + slag } & 90 & 21.9 & 522 \\
\cline { 2 - 4 } & 0 & 0.0 & 375 \\
\cline { 2 - 4 } & 30 & 0.0 & 280 \\
\cline { 2 - 4 } & 60 & 0.0 & 338 \\
\hline
\end{tabular}

\subsection{Rheology, Flow and Pumpability}

The yield stress and plastic viscosity were determined from flow curve measurements of the grout samples (see Table 3-7). These values were then used to determine whether or not the grout was pumpable under various flow rates for 1200 feet of 2 " schedule 40 piping. The results of this analysis are presented in Table 3-8 with values in italics and red indicating unacceptable values. The flow condition for all these grouts were in the laminar flow region for all flow rates. The pressure drop for a Bingham Plastic fluid was determined as detailed elsewhere (9). 
Table 3-8 Pumpability as a Function of Time for the Three Mix Designs

\begin{tabular}{|c|c|c|c|c|c|}
\hline \multirow{2}{*}{ Mix Identifier } & \multirow{2}{*}{$\begin{array}{c}\text { Time } \\
\text { (minutes) }\end{array}$} & \multicolumn{4}{|c|}{ Pressure Drop for 1200 feet of 2" Sch. 40- Piping (PSI) } \\
\hline & & $5 \mathrm{gpm}$ & 10 gpm & 15 gpm & 20 gpm \\
\hline \multirow{4}{*}{ MF 816 + slag } & 0 & 41.5 & 67.0 & 92.5 & 118 \\
\hline & 30 & 37.8 & 59.8 & 81.7 & 104 \\
\hline & 60 & 44.3 & 67.1 & 89.8 & 112 \\
\hline & 90 & 53.9 & 78.5 & 103 & 127 \\
\hline \multirow{4}{*}{ MF $1341+$ slag } & 0 & 116 & 189 & 262 & 335 \\
\hline & 30 & 130 & 183 & 234 & 285 \\
\hline & 60 & 146 & 197 & 246 & 296 \\
\hline & 90 & 160 & 210 & 257 & 305 \\
\hline \multirow{4}{*}{$\mathrm{OPC}+$ slag } & 0 & 33.7 & 67.4 & 101 & 135 \\
\hline & 30 & 25.1 & 50.3 & 75.5 & 102 \\
\hline & 60 & 30.3 & 60.7 & 91.1 & 122 \\
\hline & 90 & 85.5 & 129 & 172 & 215 \\
\hline
\end{tabular}

In general, high shear mixing will produce a dispersion which has a lower plastic viscosity. Two of the mix designs were initially blended using a high shear mixer and then with the paddle blade mixers to determine the impact of high shear on the rheological and flow conditions. The results are presented in Table 3-9. The plastic viscosity decreased significantly while the yield stress increased slightly. These results show that high shear mixing during production could improve the pumpability of the mixes and thereby increase the range of acceptable pumping rates to the coils if required. A potential drawback to high shear mixing is that it increases the temperature of the mix, which could impact the workability of the grouts.

Table 3-9 Flow and Rheological Data for High Shear vs. Low Shear Mixing

\begin{tabular}{|c|c|c|c|c|}
\hline Mix Identifier & Shear Level & $\begin{array}{c}\text { Flow } \\
\text { (inches) }\end{array}$ & $\begin{array}{c}\text { Yield Stress } \\
\text { (Pa) }\end{array}$ & $\begin{array}{c}\text { Plastic Viscosity } \\
\text { (cP) }\end{array}$ \\
\hline \multirow{2}{*}{ MF 816 + slag } & Low & 10 & 3.0 & 283 \\
\cline { 2 - 5 } & High & 9 & 3.9 & 107 \\
\hline \multirow{2}{*}{ MF 1341+ slag } & Low & 8 & 7.2 & 750 \\
\cline { 2 - 5 } & High & 7 & 10.8 & 366 \\
\hline
\end{tabular}

The flow measurements, which can be utilized in the field, were measured using two different methods. The first method followed ASTM C 939 (Figure 3-1) while the second method used a procedure developed by Savannah River National Laboratory (SRNL) (5). The results of both of these tests are provided in Table 3-10. 


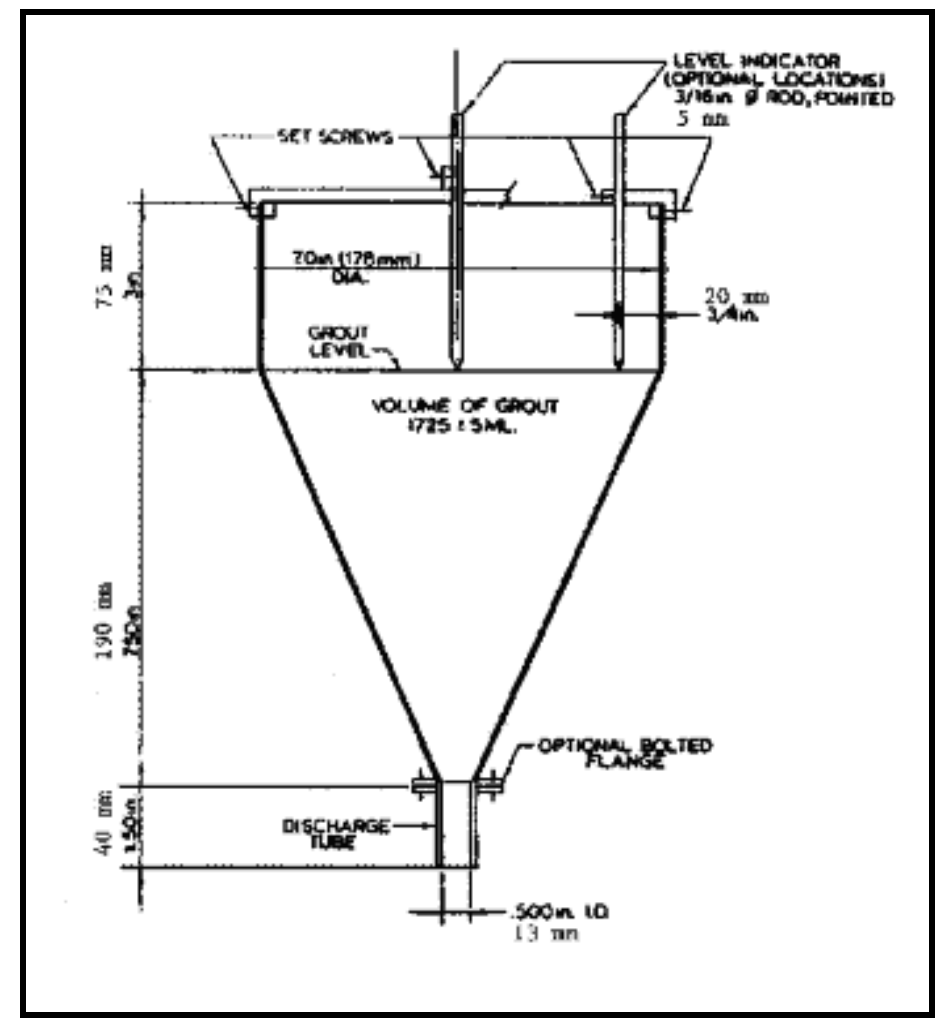

Figure 3-1 ASTM C 939 Flow Cone

Table 3-10 Flow values for the Three Mix Designs

\begin{tabular}{|c|c|c|}
\hline Mix Identifier & ASTM C 939 (seconds) & SRNL Flow (inches) \\
\hline MF 816 + slag & 18 & 10 \\
\hline MF 1341 + slag & 60 & 7 \\
\hline OPC + slag & Not measured & 7 \\
\hline
\end{tabular}

The flow measurement detailed in ASTM C 939 is routinely used in the field with grouts as a quality control measure. In this method, $1725 \mathrm{~mL}$ of grout are placed into a flow cone. The discharge is then opened and the time required for the grout stream to break from a steady stream through the discharge is recorded. The MF 816 cable grout vendor states that this time normally ranges between 20 to 30 seconds for a water to MF 816 ratio of 0.30 . The flow result for MF 816 + slag measured at SRNL was 18 seconds. This faster flow time is most likely accounted for by the facts that the mix included slag and had a w/cm ratio of 0.33 . The mix containing MF 1341 + slag had a 60 second time of flow which is significantly longer than the MF 816 + slag mix. This is consistent with the higher yield stress and plastic viscosity of the MF $1341+$ slag mix. The second method used to measure flow was developed at SRNL (5), where a right cylinder is filled with grout, quickly raised and the diameter of the grout flow circle measured after $~ 1$ minute (no additional flow observed). The diameter of the flow circle with the SRNL cylinder flow test method is generally consistent with this data in that the MF $816+$ slag mix produced a flow circle that was three inches greater in diameter than the MF $1341+$ slag mix 
(i.e., the MF 816 +slag grout had a better flow). It is interesting that the flow of the grout is not instantaneous for the two mixes containing cable grouts. Rather, the grout slowly creeps to the final diameter. The OPC + slag mix on the other hand, flowed to 7 inches very quickly.

It is recommended that the ASTM C 939 flow method be used during the full scale demonstration at CETL as well as at SRS prior to placement within the actual cooling coils. This flow measurement in seconds provides a quality control value to validate the grout mix for flowability as well as providing insight into the mixing conditions and environmental conditions.

\subsection{Compressive Strength}

The requirement for compressive strength for these cable grouts is a value greater than 2,000 psi (1). Compressive strength values of the cured grouts were measured using 2 inch cubes of cast grout following ASTM C 942 (measurements done in triplicate) after 28 days. The 2 inch cubes were removed after one day and completely immersed in a lime saturated solution under controlled temperature until the time of measurement. Figure 3-1 shows the three cubes for the MF 816 + slag grout immediately after being removed from the lime saturated bath and just prior to compressive strength measurements.

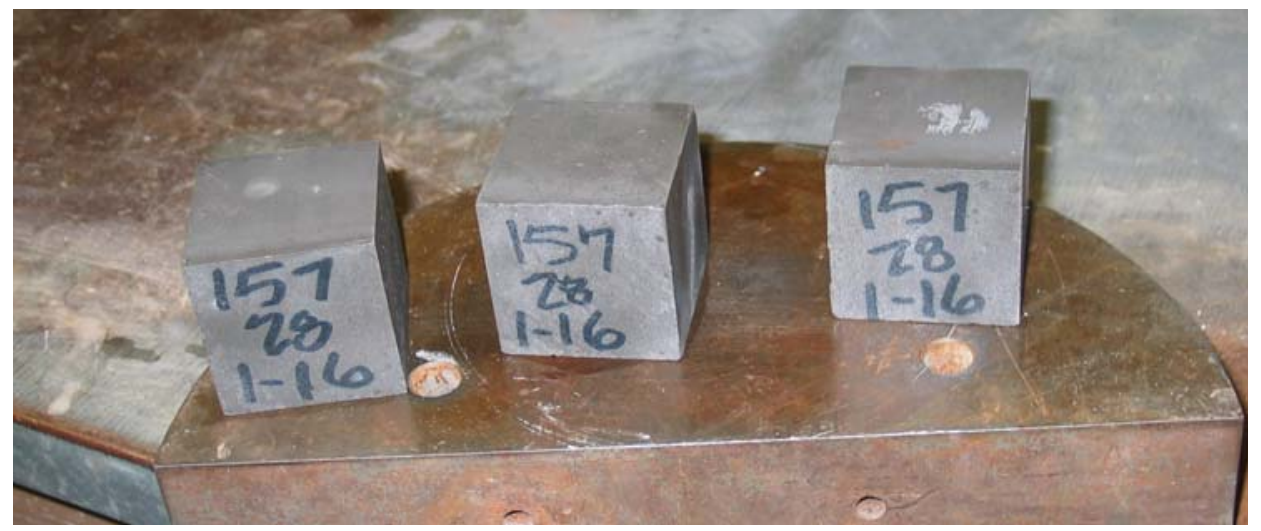

Figure 3-2 The 2 inch cubes immediately after removal from the lime saturated bath and just prior to testing.

The results for the compressive strengths of the three mix designs are presented in Table 3-11and are the average of three determinations for each grout. The values for the MF $816+$ slag mix and the OPC + slag mix were above 10,000 psi, a very high value for grouts. The MF $1341+$ slag, containing sand, had approximately half of compressive strength value of the other two mixes at 28 days of curing. The compressive strength for the MF 816 mix (without slag) reported by the vendor, and using the 2 inch cubes, is 8,500 psi after 28 days. These values of compressive strength greatly exceed the requirement of a minimum value of 2,000 psi. 
Table 3-11 Compressive Strengths of the Three Mix Designs for Cooling Coil Grout after 28 Days of Curing

\begin{tabular}{|c|c|}
\hline Mix Identifier & Compressive Strength (psi) \\
\hline MF 816 + slag & 11,100 \\
\hline MF 1341 + slag & 6,890 \\
\hline OPC + slag & 13,900 \\
\hline
\end{tabular}

These compressive strength values are those at catastrophic failure. There was some spalling of the cube as the force increased but the overall cube continued to withstand the increased force until failure. Figure 3-2 is a photograph of one of the cubes immediately after failure.

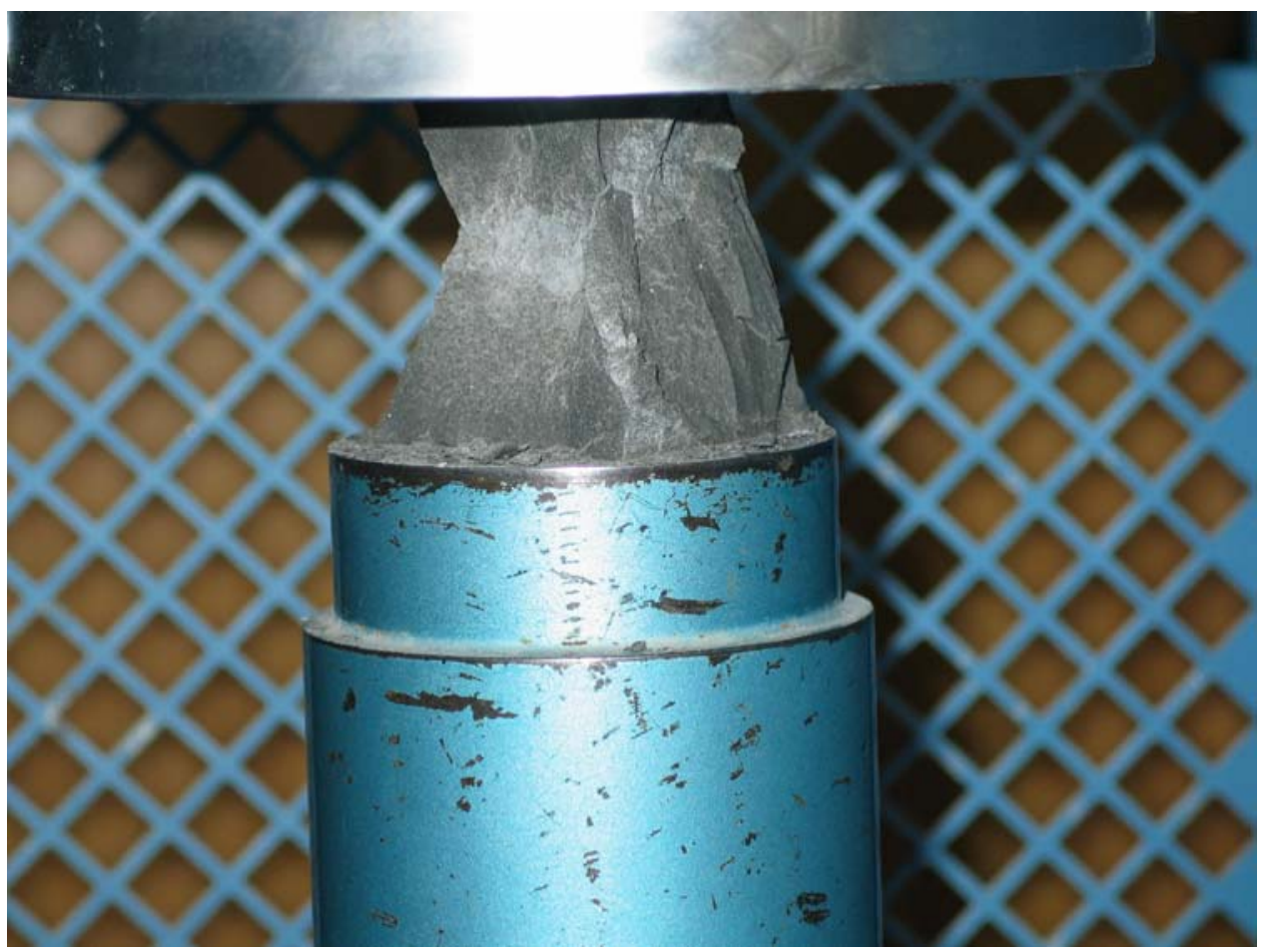

Figure 3-2 One of the cubes immediately after failure of compressive strength testing

\subsection{Porosity}

Porosity was measured for these samples as described in a previous report (7) and was measured to provide an early indication of the permeability of the mixes. The total porosity values (Table 3-12) are relatively constant and low for all the mixes. For example, Saltstone mixes have porosities typically in the range of $60 \%$. The degree of hydration values (in units of w/cm) are relatively high and show that most of the cementitious materials have reacted (6). The MF 1341 +slag mix contains sand as part of the aggregate in the MF 1341, provides a lower apparent value of the degree of hydration. If the sand contribution is subtracted, then the actual degree of hydration is higher and closer to the porosity value obtained with the MF $816+$ slag mix. The 
OPC + slag mix had a degree of hydration of 0.137 after only eight days. Complete hydration is represented by a w/cm degree of hydration value of $\sim 0.18$ (7). The low porosity and high degree of hydration indicator for all three mixes suggest that the samples should have low permeability in the absence of cracking (see Section 3.11).

Table 3-12 Porosity Measurements for Samples at Various Curing Times

\begin{tabular}{|c|c|c|c|c|c|}
\hline Identifier & $\begin{array}{c}\text { Cementitious } \\
\text { Material (CM) }\end{array}$ & $\begin{array}{c}\text { Water to CM } \\
\text { Ratio }\end{array}$ & $\begin{array}{c}\text { Cure Time } \\
\text { (Days) }\end{array}$ & $\begin{array}{c}\text { Porosity } \\
\text { (Percent) }\end{array}$ & $\begin{array}{c}\text { Degree of Hydration } \\
\text { Water to CM }\end{array}$ \\
\hline TR374 & $90 \%$ MF 816 + 10 \% Slag & 0.33 & 8 & 35 & 0.103 \\
\hline TR377 & $100 \%$ MF 816 & 0.33 & 8 & 36 & 0.099 \\
\hline TR393 & $90 \%$ MF 816 + 10 \% Slag & 0.33 & 15 & 36 & 0.102 \\
\hline TR396 & $90 \%$ MF 816 + 10 \% Slag & 0.33 & 15 & 34 & 0.107 \\
\hline TR394 & $90 \%$ MF 1341 + 10 \% Slag & 0.29 & 15 & 35 & 0.072 \\
\hline TR397 & $90 \%$ MF 1341 + 10 \% Slag & 0.29 & 15 & 34 & 0.074 \\
\hline TR376 & $90 \%$ OPC and 10\% Slag & 0.35 & 8 & 32 & 0.137 \\
\hline
\end{tabular}

\subsection{Heat of Hydration}

The heats of hydration of the three mixes were measured at $25{ }^{\circ} \mathrm{C}$ over a 20 day period. Although there is no limit on the amount of heat produced for the cooling coil grout, this data was obtained to (1) support the analysis of the temperature rise data of the grout in the cooling coils for the CETL demonstration and (2) for use when considering sequence options for filling the coils within the HLW tanks (e.g., before or after addition of the tank closure grout). The amount of heat generated for the grouts was different for all three mixes. The heat as a function of time data are presented in Figures 3-3, 3-4 and 3-5, the heat flow for MF 816 plus slag mix is presented in Figure 3-6 and all of the results are summarized in Table 3-13. The values of the heat flow and total heat evolved are normalized to the fraction of solids in the formulation. Normally the solids are cementitious materials but for this task, the inclusion of sand in the MF 1341 mix was included as part of the solids fraction.

The MF 816 + slag mix generated $278 \mathrm{~J} / \mathrm{g}$ after 20 days compared to the MF 1341 + slag mix which generated only $206 \mathrm{~J} / \mathrm{g}$ after the same time period. As discussed above, this is due to the fact that MF 1341 contains sand in the grout mix which provides no contribution to the amount of heat generated. The impact of heat generation to the overall system is unknown but was assumed to be insignificant for the selection process.

The OPC + slag mix generated $346 \mathrm{~J} / \mathrm{g}$ of cementitious material after 20 days. This is close to the amount of heat normally generated for a Portland cement based grout after 20 days. 


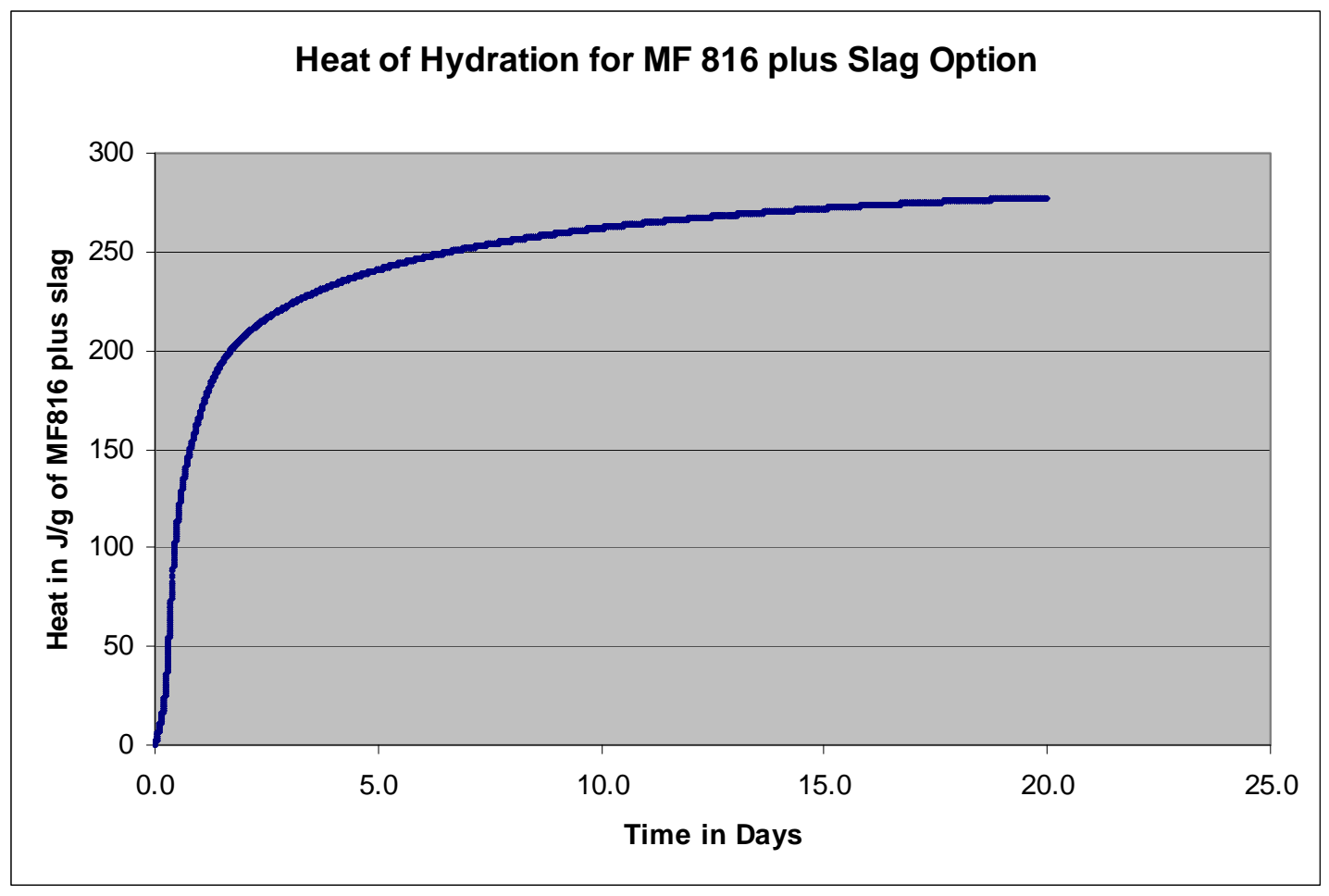

Figure 3-3 Normalized heat of hydration for the MF 816 + slag mix

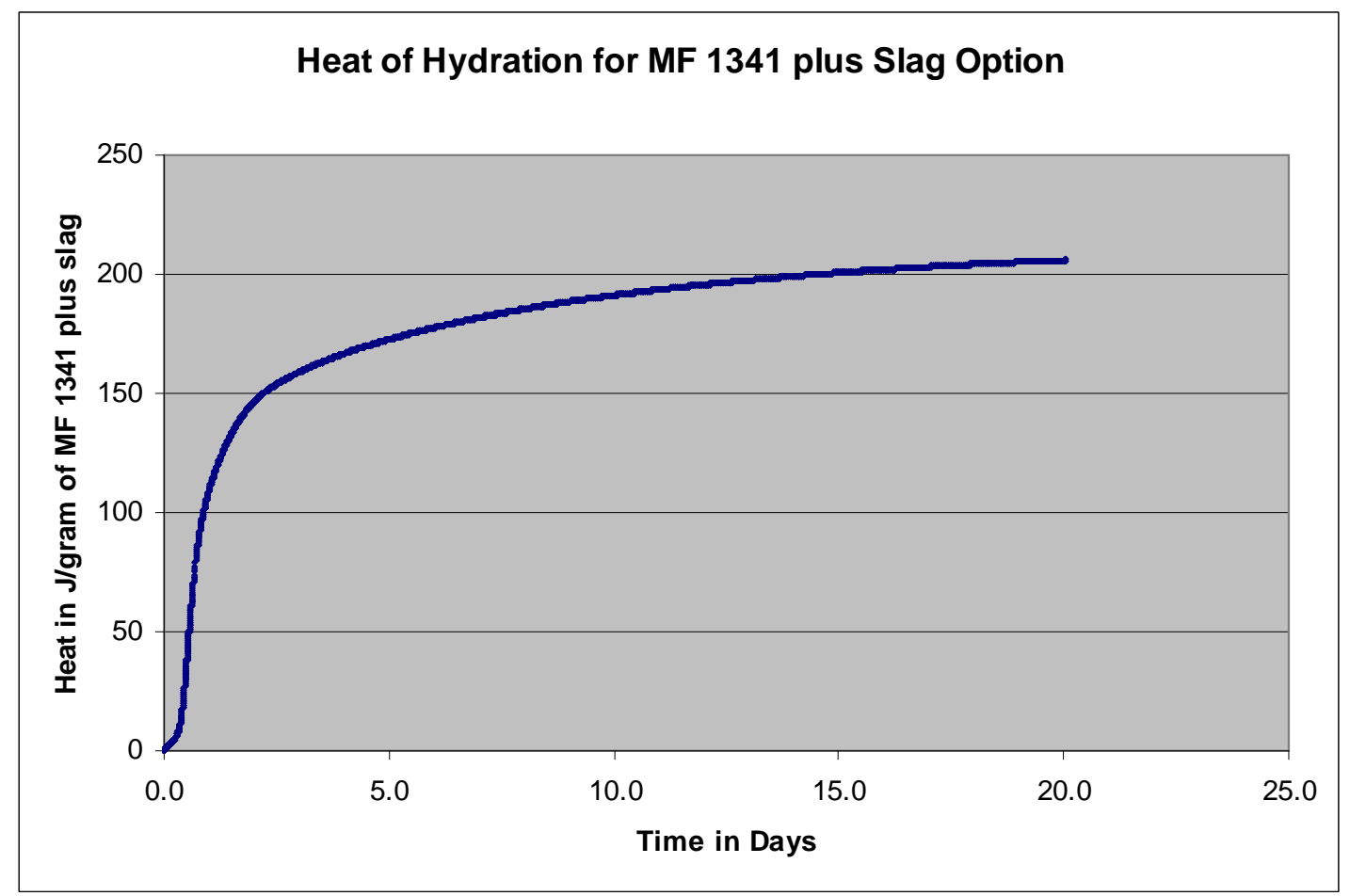

Figure 3-4 Normalized heat of hydration for the MF 1341 + slag mix 


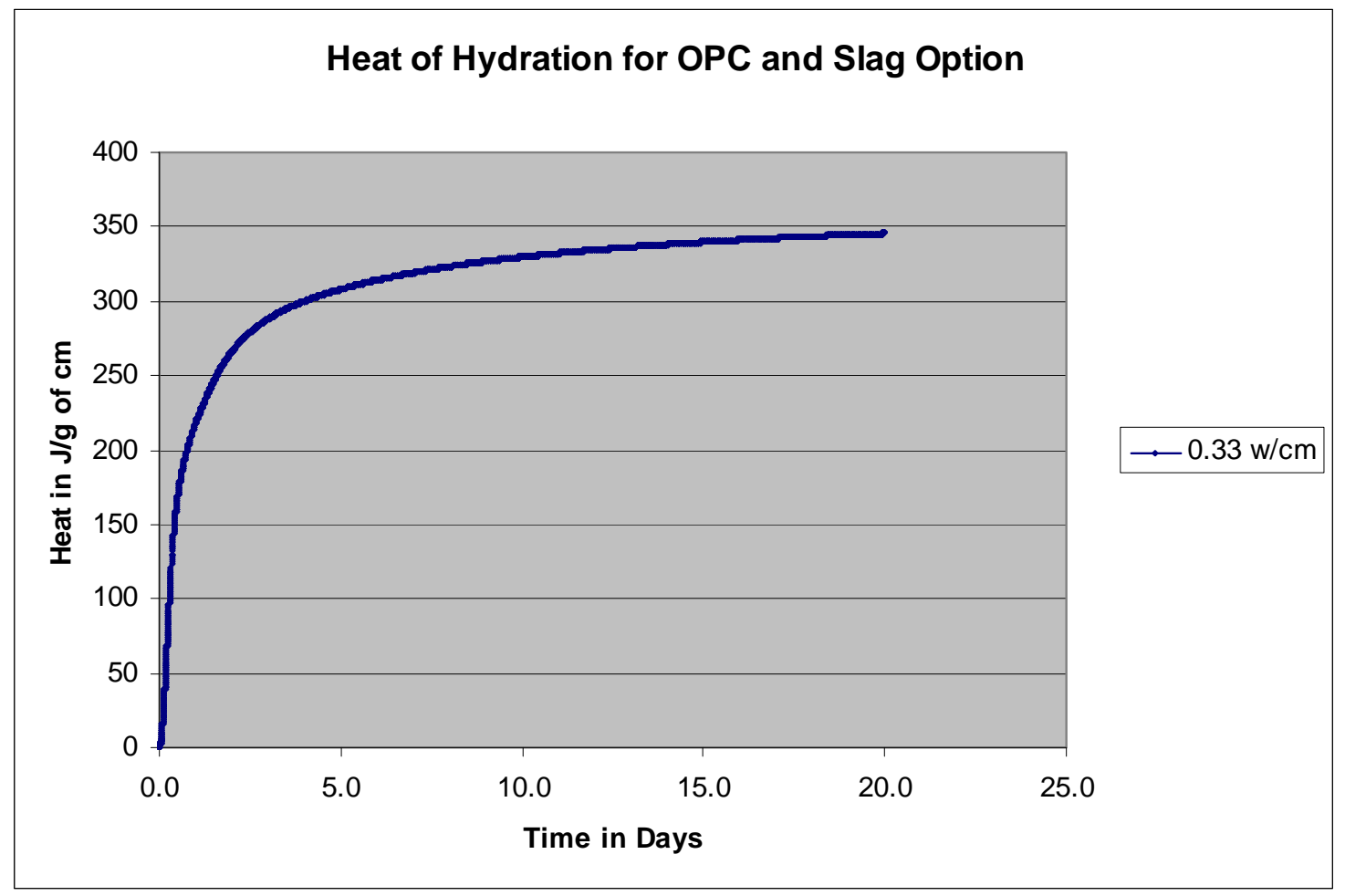

Figure 3-5 Normalized heat of hydration for the OPC + slag mix

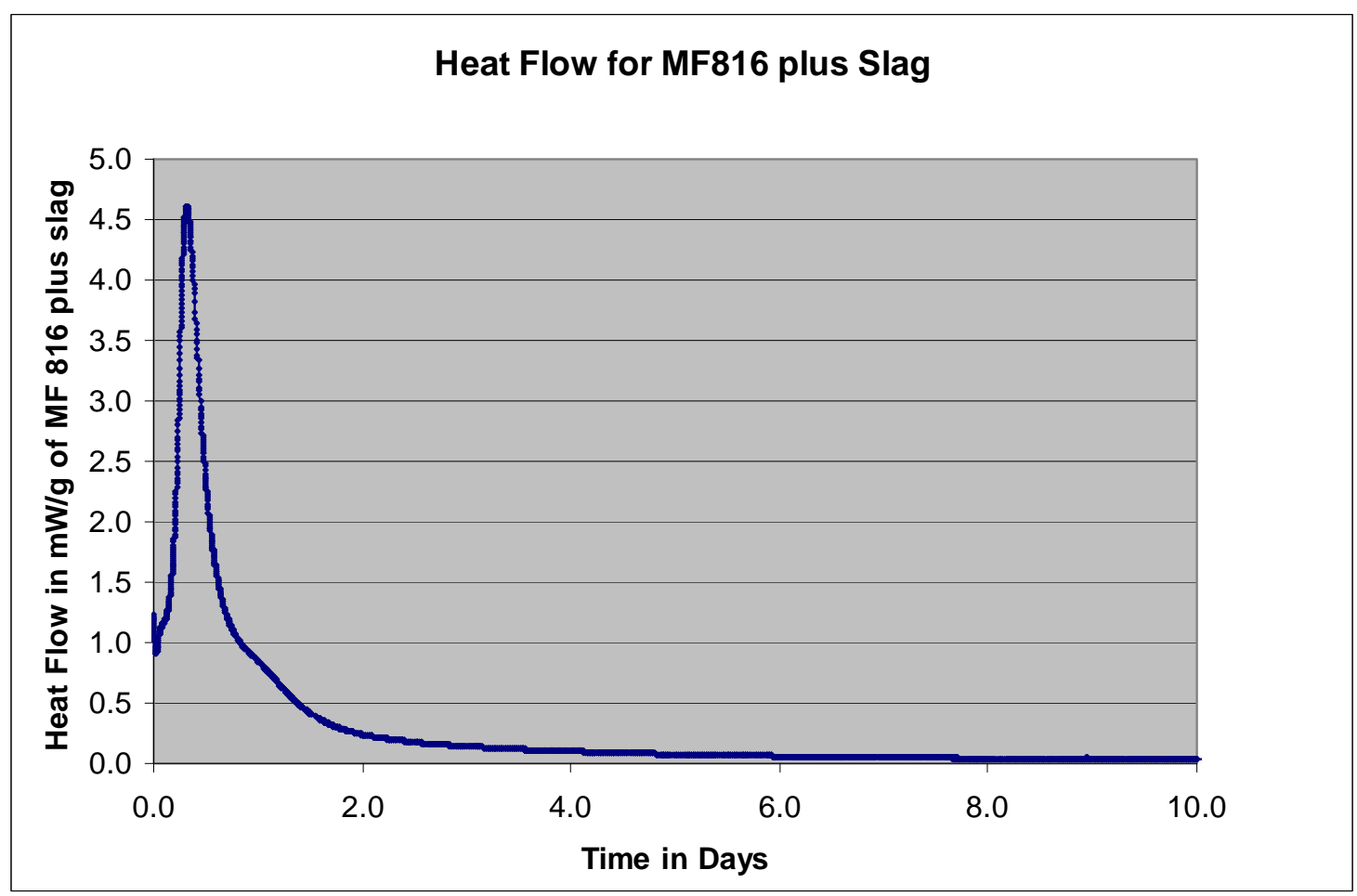

Figure 3-6 Normalized heat flow for the MF 816 and slag mix 
Table 3-13 Normalized Heat of Hydration Data after 20 Days

\begin{tabular}{|c|c|c|c|c|c|}
\hline \multirow{2}{*}{$\begin{array}{c}\text { Mix } \\
\text { Identifier }\end{array}$} & \multirow{2}{*}{ Type } & Time & \multicolumn{2}{|c|}{ Heat of Hydration (J/g) } & Peak Time \\
\cline { 3 - 6 } & & (Days) & solids & grout & Hours \\
\hline TR374 & MF 816 + slag & 20 & 278 & 209 & 8 \\
\hline TR388 & MF 1341 + slag & 20 & 206 & 160 & 14 \\
\hline TR376 & OPC + slag & 20 & 346 & 257 & 6 \\
\hline
\end{tabular}

\subsection{Shrinkage/Expansion}

The TTR (1) requires that the cooling coil grout formulation be developed to limit shrinkage. Consequently, the change of length of a cast bar of grout was measured over a 28 day period following ASTM C 157. The cast samples of MF 816 + slag and MF 1341 + slag grouts were removed from the molds after one day and transferred to a controlled environment room at 100 $\%$ relative humidity $(\mathrm{RH})$ and $25{ }^{\circ} \mathrm{C}$. Figure $3-3$ shows one of these bars in the measurement position. Table 3-14 presents the results of this test. After 28 days at $100 \% \mathrm{RH}$, the bars had expanded $\sim 0.04 \%$.

These bars were then removed from the controlled environment room and placed in the laboratory which had a lower RH of $\sim 60 \%$ at ambient temperature. Under this condition, the bars lost mass due to water evaporation and showed shrinkage of $\sim 0.06 \%$ after 14 days.

Table 3-14 Expansion/Shrinkage Data for the Grouts

\begin{tabular}{|c|c|c|}
\hline Mix Identifier & $\begin{array}{c}\text { Expansion at 100 \% RH } \\
\text { \% after 28 days }\end{array}$ & $\begin{array}{c}\text { Shrinkage at ambient RH } \\
\text { \% after 14 days }\end{array}$ \\
\hline MF 816 + slag & 0.035 & 0.066 \\
\hline MF 1341 + slag & 0.047 & 0.056 \\
\hline OPC + slag & Not measured & Not measured \\
\hline
\end{tabular}




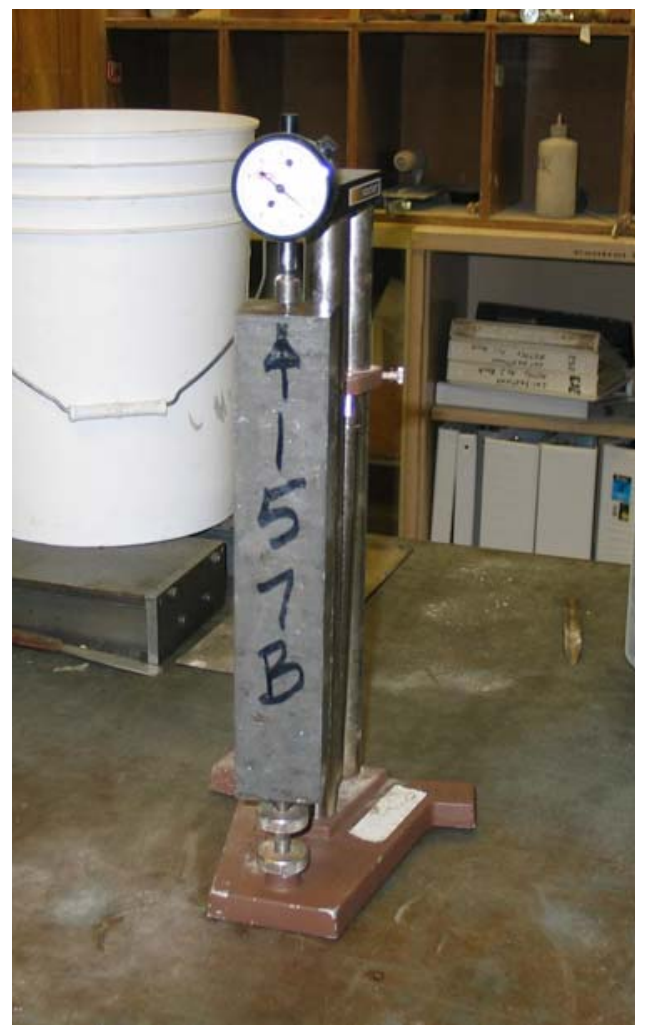

Figure 3-7 Cast bar in a micrometer used to measure shrinkage and expansion (N-Area)

These results reflect minor changes in length depending upon the environmental conditions. When the grout is placed into the cooling coil, it is a closed environment, which is essentially equivalent to the initial measurement conditions of $100 \%$ RH. It is expected that the grout will expand, which is the expectations of the grout formulation of the vendor. Visual observation of the top, open part of the mold showed a slight expansion of the grouts had occurred after one day of curing. Although samples of the OPC + slag mix were not cast as part of this test, visual observation of the cast compressive strength samples showed that the OPC + slag grout had shrunk slightly after one day of curing. In comparison, the cast compressive strength samples for the cable grout mixes showed a slight expansion of the grout.

\subsection{Hydraulic Conductivity}

The saturated hydraulic conductivities of the mixes were measured using a flexible wall permeameter with a falling head configuration (ASTM D 5084) at MACTEC, Atlanta, Georgia. The experimental setup included (1) the use of mercury to increase the head and consequently, the detection limit and (2) water as permeant. The hydraulic conductivities measured were:

$\begin{array}{ll}\text { MF } 816 \text { + slag } & 1 \mathrm{E}-10 \mathrm{~cm} / \mathrm{sec} \\ \text { MF } 1341 \text { + slag } & 7 \mathrm{E}-10 \mathrm{~cm} / \mathrm{sec} \\ \text { OPC + slag } & 3 \mathrm{E}-10 \mathrm{~cm} / \mathrm{sec}\end{array}$


These results meet the requirement that hydraulic conductivity is at least as good as that measured for the reducing fill grout, OPDEXE-X-P-0-BS which was on the order of $10^{-8} \mathrm{~cm} / \mathrm{sec}$ (8). Therefore, the mixes readily meet the specifications. Figure 3-8 shows the experimental setup at MACTEC and Figure 3-9 shows the molds filled with the MF 816 + slag mix.

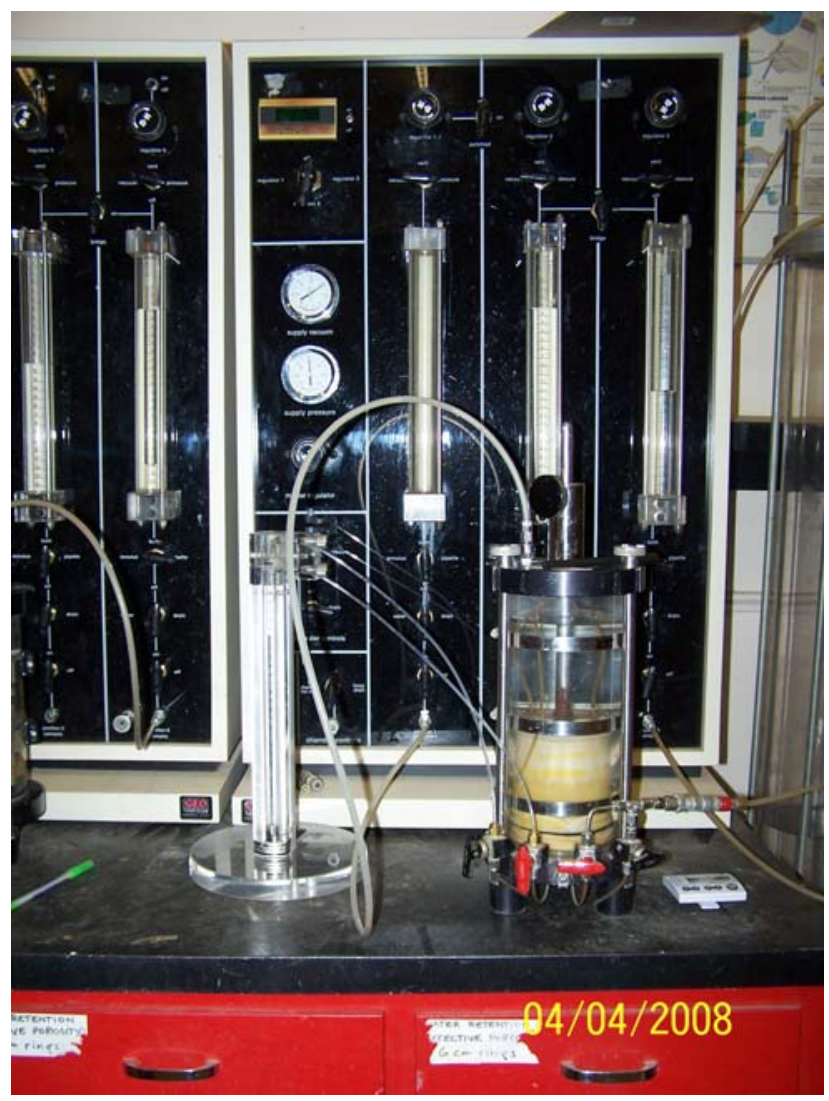

Figure 3-8 Photograph of the experimental setup at MACTEC for measurement of permeability 


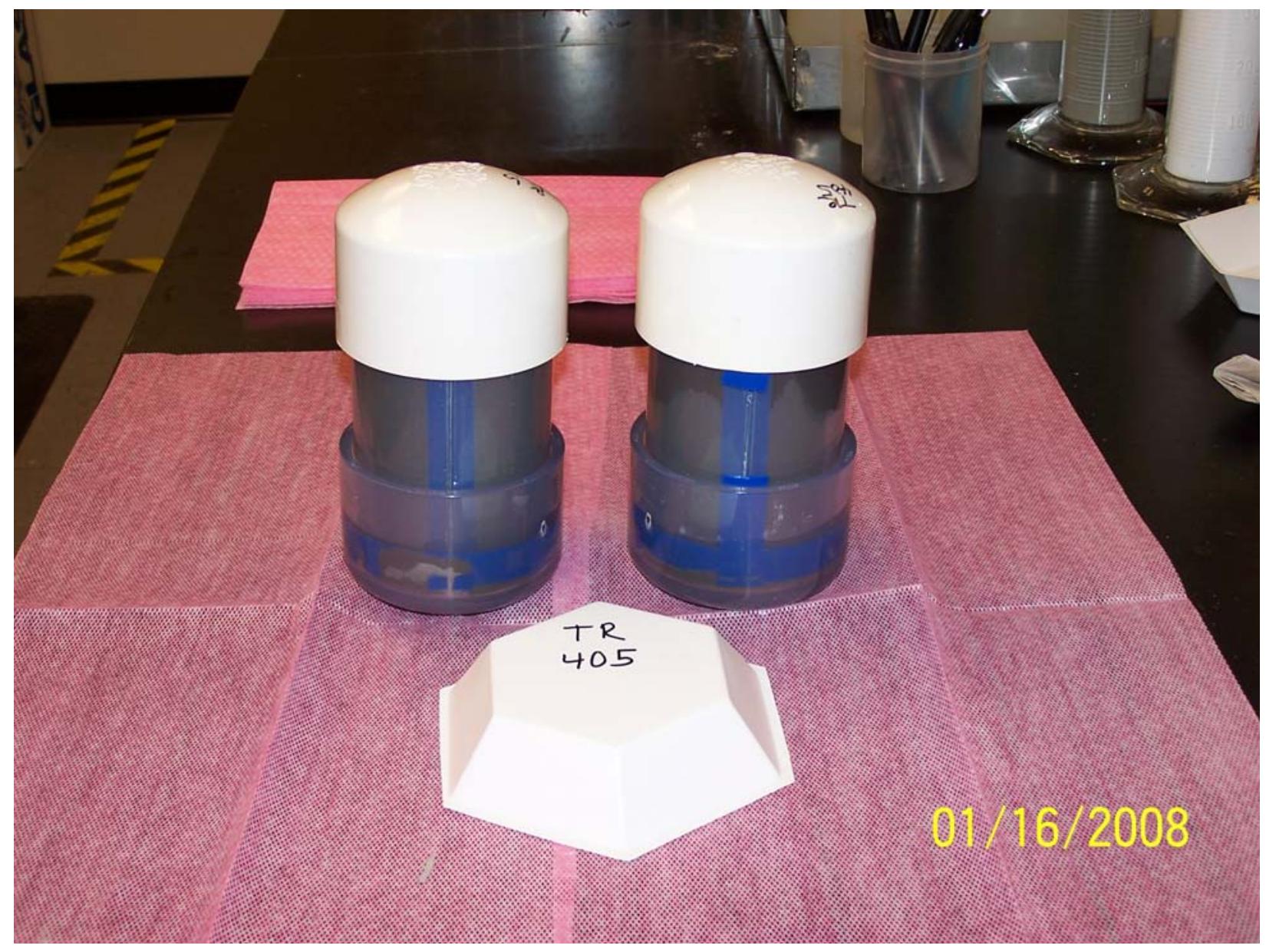

Figure 3-9 Photograph of the molds in which the samples were cast and cured for 28 days prior to removal and measurement at MACTEC (TR 405 is the mix containing MF 816 and slag).

\subsection{Air Content}

Air content is a fresh grout property and is dependent on the type of mixing system used to mix and transport the grout. It is recommended that the air content of the grout be measured at CETL under the mixing and pumping conditions of the full scale testing. Generally the air content is < $4 \%$ by volume for grouts that do not contain air-entraining admixtures.

\subsection{Impact of Chromate}

The cooling coils are filled with an aqueous solution of chromate and sodium hydroxide. The present plans for preparing the cooling coils for grout fill will be to flush them with water prior to filling them with grout. The impact of residual cooling coil liquid (containing the chromate and free hydroxide) on grout properties was part of the testing as detailed in the TTP. As a conservative approach, a simulant was batched that contained chromate at $0.006 \mathrm{M}$ and sodium hydroxide at $0.001 \mathrm{M}$, nominal concentration presently in the cooling coil fluid. 
Mixes were made using this caustic chromate simulant, MF $816+$ slag at a w/cm ratio of 0.33 and MF 1341 + slag at a water to cable grout plus slag ratio of 0.29 . There was no bleed water evident from either mix and both mixes had set within one day. The gel times were $<10$ minutes and the yield stress and plastic viscosity for both mixes were essentially identical to those reported in Table 3-7.

The compressive strengths of these two mixes were measured after 28 days of curing using samples cast in cylindrical molds (Table 3-15). It has previously been demonstrated that the values for compressive strength obtained using cylindrical molds have lower values and higher variability than those results obtained using the 2 inch cubes (5). Therefore, the results in Table 3-15 between the two samples are reasonably consistent and demonstrate compliance with the compressive strength requirements.

Table 3-15 Compressive Strength Values for Mixes Made With and Without Chromate

\begin{tabular}{|c|c|c|}
\hline \multirow{2}{*}{ Mix Identifier } & \multicolumn{2}{|c|}{ Compressive Strength (psi) } \\
\cline { 2 - 3 } & With Chromate & Without Chromate \\
\hline MF 816 + slag & 4700 & 7400 \\
\hline MF 1341 + slag & 3400 & 4890 \\
\hline
\end{tabular}

These results, using a conservatively high amount of chromate and free hydroxide in the cooling coil solution, demonstrate that acceptable grout properties will be obtained in the presence of residual chromate and free hydroxide ions in the water. 


\subsection{CONCLUSIONS}

This report summarizes the results of a grout formulation task to produce a mix design for filling cooling coils prior to final closure of HLW tanks at Savannah River Site. The conclusions of this study are as follows:

- The mix design that is composed of $90 \%$ MF 816 and $10 \%$ BFS with a water to cementitious material ratio of 0.33 produces a grout which meets the requirements defined in the TTR. This is the mix design that is recommended for large scale testing at CETL (see Recommendation Section).

- An alternative mix using $90 \%$ MF 1341 and $10 \%$ BFS with a water to premix ratio of 0.29 is also acceptable and produces less heat per gram than the MF 816/slag mix. However this MF 1341 mix has a higher plastic viscosity than the MF 816/slag mix due to the presence of sand in the MF 1341 cable grout. Nevertheless, the higher viscosity may still meet the requirements and/or be improved by a short period of high shear mixing during production.

- The mix made with $90 \%$ OPC and $10 \%$ BFS exhibited some initial shrinkage as well as initial bleed water. The initial bleed water was reabsorbed under laboratory conditions within one day but could present an issue in the field. The shrinkage may be a more significant concern due to the potential of introducing pathways for water inleakage.

- The mixes have not been optimized for large scale production. It may be possible for example to adjust the water to cementitious materials ratio to provide improved performance of these mixes for filling cooling coils based on the results and conclusions of the full scale testing at CETL. 


\subsection{RECOMMENDATIONS}

Recommendations from this study are to:

- Use the MF 816 plus slag mix design for large scale testing at CETL.

- Ensure that a backup mixing/pumping system is either integrated into the system or is available for immediate use in case of a pump or mixer failure of the primary system.

- Implement the ASTM C 939 flow method at CETL (as well as at SRS prior to placement within the actual cooling coils). This flow measurement provides a quality control value to validate the grout mix and provide insight into the impact of mixing and environmental conditions on the grout mix.

- After receiving feedback from the full scale testing at CETL, conduct a laboratory scale investigation to determine the impact of operational variation on the properties of the grout. The purpose of this proposed variability testing is to better understand the limits of the operational variations (such as temperature), mixing time, and to identify possible approaches for remediation to ensure that the grout produced will flow effectively in the coils while still meeting the performance requirements. 


\subsection{REFERENCES}

1 Adkins, B. J., 2007. “Develop Cooling Coil Closure Technology Grout Formulations,” Technical Task Request, HLE-TTR-2007-007, May 1, 2007, Washington Savannah River Company, Aiken SC 29808.

2 Harbour, J. R. and E. K. Hansen, “Task Technical and QA Plan: Cooling Coil Grout and Technology Development” WSRC-RP-2007-00384, Rev. 2, March 2008.

3 Martin, B. A., 2007. "Defining Attributes Leading to Successful Closure of Tank Cooling Coils,” LWO-PIT-2007-00021, Washington Savannah River Company, Aiken SC 29808.

4 Adkins, B. J., 2007. “Calculation of Permissible Rheology Range for Cooling Coil Grout,” April 9, 2007, G-CLC-G-00111, Revision 0, Washington Savannah River Company, Aiken SC 29808.

5 Harbour, J. R., T. B. Edwards, E. K. Hansen and V. J. Williams, "Variability Study for Saltstone”, WSRC-TR-2005-00447, Rev. 0, October, 2005.

6 Harbour, J. R., V. J. Williams and T. B. Edwards, "Heat of Hydration of Saltstone Mixes - Measurement by Isothermal Calorimetry” WSRC-STI-2007-00263, Rev. 0, May 2007.

7 Harbour, J. R., V. J. Williams, T. B. Edwards, R. E. Eibling and R. F. Schumacher, "Saltstone Variability Study - Measurement of Porosity", WSRC-STI-2007-00352, Rev. 0, August, 2007.

8 Langton, C. A., “Grout Formulations and Properties for Tank Farm Closure” WSRC-STI2007-00641, Rev. 0, November 2007.

9 Hansen, E. K., “Tank 51 Sludge Batch 4 Transfer to Tank 40”, WSRC-STI-2006-00218, Rev. 0, 2006. 